hybridization, we investigated if Mash 1 gene expression occurs in rat taste buds. Further, we examined dynamics of Mash 1 expression in the process of degeneration and regeneration in rat denervated taste buds. The results indicate that Mash 1 is expressed in cells of the taste bud cell lineage. Denervation and regeneration experiments show that the expression of Mash 1 requires gustatory innervation. We conclude that Mash 1 is expressed in cells of the taste bud lineage, and that the expression of Mash1 in rat taste buds is dependent upon gustatory innervation.

\title{
15. 遲延視覚誘導性䪽運動課題を遂行するサルの皮質運動関連領野の役割
}

○吉野 賢一·河岸 重則·高月 義子·天野仁一朗

九菌大·口科

一次運動野（MI）およびこれに隣接する運動前野腹倒部（PMv）の口腔顔面領域は，視覚刺激に誘導される顎運 動遂行時に異なる役割を演じていると考えられている．そこで特に䪽運動準備期および運動開始時に注目し，遅延視 覚誘導性靧運動課題を遂行するサルの MI および PMv からニューロン活動を記録した．記録した課題関連ニューロ ンのうち $7.7 \%$ MI ニューロンおよび $35.4 \%$ PMvニューロンが準備関連活動を示した. MI と PMvで認めら れた多くの準備関連ニューロン $(66.7 \%)$ は方向選択性を有し，開口または閉口試行のいずれか一方で持続的な反

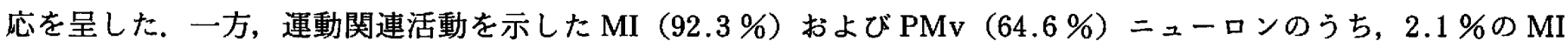
ニューロンおよび $15.1 \%$ PMv ニューロンは開口と閉口の両試行で同じ様な活動の変化を示した. 以上の結果よ り，主として MI は顎運動の発現や遂行時の咀嚼笳のコントロールに, PMv は試行を遂行するための行動制御を行 うと同時に，頭運動準備に関与していると考えられる.

Functional properties of the primary motor cortex and ventral premotor cortex in the monkey during a visually guided jaw movement task with a delay period

Kenichi Yoshino, Shigenori Kawagishi, Yoshiko Takatsuki and Niichiro Amano (Department of Oral Neuroscience, Kyushu Dental College)

This study investigated neuronal activity in the primary motor cortex (MI) and the premotor cortex (PMv) while a monkey performed the task. When the monkey executed the jaw movements, 48 MI and $53 \mathrm{PMv}$ neurons showed movement-related activities. Considering the activity patterns of them, the movement-related neurons probably contributed to the initiation of jaw movements and may be involved in controlling and/or maintaining jaw position. We also detected sustained activity during the delay period in $4 \mathrm{MI}$ and $29 \mathrm{PMv}$ neurons and defined these neurons as being set-related neurons. It is thought that these set-related neurons are involved in the preparation for the subsequent jaw movement. These results suggest that the MI may be involved predominantly in the initiation and control of jaw movements, and that the PMv may be involved in motor preparation and may play a role as a higher-order motor area related to the initiation and control of jaw movements.

\section{6. ラットの咀霹筋運動ニューロンのエネルギー代謝系酵素活性について}

○河岸 重則·吉野 賢一·高月 義子·柳瀬 益正·天野仁一朗

九歯大·口科

ラットの咀嚼筋運動ニューロンの酸化系 $(\mathrm{SDH})$ および解糖系酵素 $(\alpha-\mathrm{GPD})$ 活性を測定し, 細胞体サイズとの 相関関係について調べた. 咬筋（閉口筋）と顎二腹筋前腹（開口筋）の運動ニューロンを蛍光色素でラベルした後, 脳幹を取り出し直ちに液体堂素で東結, 厚さ $20 \mu \mathrm{m}$ の連続凍結切片を作製した. 蛍光顕微鏡下, 蛍光色素でラベル された運動ニューロンを同定，次いで切片をSDH または $\alpha-G P D$ 活性染色に供した．染色された細胞体の $470 \mathrm{~nm}$ の吸光度を測定, 酵素活性とした. 細胞体のサイズは画像解析装置を用い測定, $25 \mu \mathrm{m}$ 以上の直径をもつものを $\alpha$ 運動ニューロンとして解析の対象とした.SSH 活性は両筋運動ニューロンで細胞体サイズと弱い相関関係があった （咬筋運動ニューロン, $\mathrm{r}=-0.283, \mathrm{n}=214, \mathrm{p}<0.001$; 顎二腹筋前腹運動ニューロン, $\mathrm{r}=-0.317, \mathrm{n}=141, \mathrm{p}<$ 